\title{
Advanced age, altered level of consciousness and a new diagnosis of diabetes are independently associated with hypernatreamia in hyperglycaemic crisis
}

\author{
Chukwuma O Ekpebegh ${ }^{1}$, Benjamin Longo-Mbenza ${ }^{1 *}$, Augustin Nge-Okwe ${ }^{2}$, Anthonia O Ogbera $^{3}$ and \\ Nomawethu T Tonjeni ${ }^{1}$
}

\begin{abstract}
Background: There is limited literature on hypernatreamia in the setting of hyperglycaemic crisis. This is despite the fact that the presence of hypernatreamia may impact on the classification of hyperglycaemic crisis and its management particularly with regards to the nature of fluid therapy. We determined the prevalence of hypernatreamia and its associated factors at presentation for hyperglycaemic crisis.

Methods: This was a retrospective review of data for hyperglycaemic crisis admissions in Nelson Mandela Academic Hospital, Mthatha, South Africa. The prevalence of hypernatreamia (uncorrected Serum Sodium at presentation $>145 \mathrm{mmol} / \mathrm{L}$ ) was determined. Hyperosmolality was defined by calculated effective osmolality $>320$ mosmols $/ \mathrm{Kg}$. Multivariate logistic regression was undertaken using variables that were statistically significant in univariate analysis to ascertain those that were independently associated (Odds Ratio (OR) with 95\% Confidence Interval (CI)) with hypernatreamia.

Results: The prevalence of hypernatreamia in our admissions for hyperglycaemic crisis was $11.7 \%(n=32 / 273$ including 171 females and 102 males). All admissions with hypernatreamia met the criteria for hyperosmolality. Age $\geq$ 60 years $(\mathrm{OR}=3.995 \% \mathrm{Cl} 1.3-12.3 ; \mathrm{P}=0.018)$, Altered level of consciousness $(\mathrm{OR}=8.895 \% \mathrm{Cl} 2.3-32.8 ; \mathrm{P}<0.001)$ and a new diagnosis of diabetes $(\mathrm{OR}=3.795 \% \mathrm{Cl} 1.2-11.5 ; \mathrm{P}=0.025)$ were independently associated with hypernatreamia.

Conclusion: The prevalence rate of hypernatreamia in hyperglycaemic admissions was high with all hypernatreamic admissions meeting the criteria for hyperosmolality. Advanced age, altered conscious level and a new diagnosis of diabetes were independently associated with hypernatreamia.
\end{abstract}

Keywords: Hypernatreamia Hyperglyceamic crisis, prevalence, determinants, South Africa

\section{Background}

Serum sodium measurement is useful in the management of hyperglycaemic crisis as it enables the determination of serum osmolality and anion gap [1]. Hyponatreamia, albeit, a pseudo phenomenon is the predominant serum sodium abnormality reported in hyperglycaemic emergencies $[2,3]$. While there is considerable literature on

\footnotetext{
* Correspondence: longombenza@yahoo.fr

'Department of Internal Medicine, Faculty of Health Sciences, Walter Sisulu University/Nelson Mandela Academic Hospital, Mthatha, Eastern Cape Province, South Africa

Full list of author information is available at the end of the article
}

hypernatreamia in general [4-7], data on hypernatreamia occurring in the context of hyperglycaemic crisis is limited. Hypernatreamia can have varied aetiology including diabetes insipidus, mineralocorticoid excess, infusions of hypertonic saline and sodium bicarbonate [5]. However, a raised serum sodium level at presentation of hyperglycaemic crisis usually reflects marked dehydration due to excessive free water loss from osmotic diuresis [8]. Measures such as vigorous fluid replacement, use of hypotonic fluids and prophylactic anticoagulation may be recommended in the setting of hypernatreamia complicating hyperglycaemic crisis. We assessed the prevalence

\section{C) Biomed Central}


and factors associated with hypernatreamia in a cohort of patients admitted with hyperglycaemic crisis at the Nelson Mandela Academic Hospital (NMAH). The NMAH is a tertiary public health facility situated in the Eastern Cape Province of South Africa and serves a predominantly indigent rural population of about 1.7 million people. The NMAH receives referrals from primary and secondary health care facilities in its area of drainage.

\section{Methods}

This is a retrospective review of hospital records of admissions for hyperglycaemic crisis during the two year periods of 2008 and 2009. Readmissions of the same patient were included as the levels of serum sodium at presentation may vary in different admissions. The prevalence of hypernatreamia at presentation (as a percentage of total admissions for hyperglycaemic crisis) and its associated factors were determined. Ethical approval was obtained from the Walter Sisulu University.

\section{Definitions}

Hypernatreamia was defined as uncorrected serum sodium at presentation above $145 \mathrm{mmol} / \mathrm{L}$, hypotension as systolic blood pressure (SBP) $<90 \mathrm{~mm} / \mathrm{Hg}$, hyperosmolality as calculated effective osmolality [9] $>320$ mosmols $/ \mathrm{Kg}$, hyperchloreamia as serum chloride $>104 \mathrm{mmol} / \mathrm{L}$, elevated serum urea as serum urea $>7 \mathrm{mmol} / \mathrm{L}$, leukocytosis as white blood count (WBC) $>10 \times 10^{6} / \mathrm{mm}^{3}$ and thrombocytopenia as platelet count $<150 \times 10^{6} / \mathrm{mm}^{3}$. Types of hyperglycaemic crisis as (a) non-hyperosmolar ketoacidosis: blood glucose $>13.9 \mathrm{mmol} / \mathrm{L}$ with serum bicarbonate $<18 \mathrm{mmol} / \mathrm{L}$ and calculated effective osmolality $\leq 320$ mosmols $/ \mathrm{Kg}$, (b) hyperosmolar ketoacidosis: blood glucose $>13.9 \mathrm{mmol} / \mathrm{L}$ with serum bicarbonate $<18 \mathrm{mmol} / \mathrm{L}$ and calculated effective osmolality $>320 \mathrm{mosmols} / \mathrm{Kg}$, (c) hyperosmolar non-ketotic state: blood glucose $>33.3$ $\mathrm{mmol} / \mathrm{L}$ with serum bicarbonate $\geq 18 \mathrm{mmol} / \mathrm{L}$ and calculated effective osmolality $>320 \mathrm{mosmols} / \mathrm{Kg}$, and (d) hyperglycaemia: blood glucose $>13.9 \mathrm{mmol} / \mathrm{L}$ with serum bicarbonate $\geq 18 \mathrm{mmol} / \mathrm{L}$ and calculated effective osmolality $\leq 320$ mosmols/Kg were as previously defined [10]. Hyperglycaemia without ketoacidosis or hyperosmolality was considered to be in crisis where treatment with intravenous fluids and insulin infusion were considered necessary by the attending medical staff.

\section{Statistical analysis}

Continuous and categorical variables were expressed as mean \pm SD and percentages (\%) respectively. Mean of continuous variables were compared with students t test while categorical variables were compared with Chisquare test. The prevalence of hypernatreamia was determined and factors associated with hypernatreamia were assessed using univariate and multivariate analysis.
The multivariate Odds ratios (OR) and corresponding $95 \%$ confidence intervals $(95 \% \mathrm{CI})$ were obtained in logistic regression model. A P-value $<0.05$ was taken as statistically significant. All data analysis was done with statistical package for social sciences (SPSS) software version 18 for windows (SPSS Inc, Chicago, Il, USA).

\section{Results}

There were 273 admissions with serum sodium results. Four of these 273 admissions who only had blood glucose readings as 'high' on glucometer testing and no documented laboratory blood glucose values in their case records were excluded from any analysis involving type of hyperglycaemic crisis as the serum osmolality could not be calculated to allow for categorization into one of the 4 types of hyperglycaemic crisis. These 4 admissions were also excluded from any analysis involving corrected serum sodium. Ten individuals were admitted more than once with a range of 2-7 admissions. One hundred and seventy one (171) and 102 admissions were female and male related respectively. The proportions of admissions for the various types of hyperglycaemic crisis were: DKA $(45 \%, \mathrm{n}=121 / 269)$; $36.1 \%(\mathrm{n}=97 / 269)$ for non-hypersomolar DKA and $8.9 \%(n=24 / 269)$ for hyperosmolar DKA. Hyperosmolar non-ketotic state and hyperglycaemia accounted for $10.8 \%(\mathrm{n}=29 / 269)$ and $44.2 \%(\mathrm{n}=119 / 269)$ of all admissions respectively. The prevalence of uncorrected hypernatreamia was $11.7 \%(\mathrm{n}=32 / 273)$ while the prevalence was $30.1 \%$ when corrected for blood glucose concentration using the formula: corrected Serum Sodium in $\mathrm{mmol} / \mathrm{L}=$ Serum Sodium in $\mathrm{mmol} / \mathrm{L}+1.6$ (Plasma glucose in $\mathrm{mmol} / \mathrm{L}-5.5 \mathrm{mmol} / \mathrm{L}$ )/5.5. Table 1 shows that the majority of hypernatreamic admissions, had serum sodium levels in the range of $146-155 \mathrm{mmol} / \mathrm{L}$ with few admissions associated with a presenting uncorrected or corrected serum sodium above $165 \mathrm{mmol} / \mathrm{L}$. Table 2 shows similar gender distribution among hypernatreamic and non-hypernatreamic admissions. Both groups had comparable mean ages but the proportion of admissions associated with age $\geq 60$ years was more in the hypernatreamic than non-hypernatreamic admissions. The mean heart rate $(111.6 \pm 16.7$ versus $100.7 \pm$ 21 beats per minute, $\mathrm{P}=0.03$ ) was higher in the hypernatreamic than non-hypernatreamic admissions. Systolic blood pressure $(111 \pm 29.1$ versus $128.9 \pm 27.9 \mathrm{~mm} / \mathrm{Hg}$, $\mathrm{P}=0.04)$ and diastolic blood pressure $(65.1 \pm 22.7$ versus $78.8 \pm 19.2 \mathrm{~mm} / \mathrm{Hg}, \mathrm{P}=0.002)$ were both lower in the hypernatreamic than non-hypernatreamic admissions. Table 2 also shows that hypotension, altered level of consciousness and a new diagnosis of diabetes mellitus were all significantly associated with hypernatreamia in univariate analysis. Table 3 shows admissions with hypernatremia at presentation to be associated with 
Table 1 Proportions of admissions with various degrees of hypernatreamia based on uncorrected and corrected serum sodium levels.

\begin{tabular}{lll}
\hline & $\begin{array}{l}\text { Hypernatreamia based on uncorrected Serum sodium } \\
\mathbf{N}=\mathbf{2 7 3}\end{array}$ & $\begin{array}{l}\text { Hypernatreamia based on corrected serum sodium } \\
\mathbf{N}=\mathbf{2 6 9}\end{array}$ \\
\hline $146-155 \mathrm{mmol} / \mathrm{L}$ & $6.2 \%(\mathrm{n}=17 / 273)$ & $16 \%(\mathrm{n}=43 / 269)$ \\
$156-165 \mathrm{mmol} / \mathrm{L}$ & $4.8 \%(\mathrm{n}=13 / 273)$ & $10.8 \%(\mathrm{n}=29 / 269)$ \\
$>165 \mathrm{mmol} / \mathrm{L}$ & $0.7 \%(\mathrm{n}=2 / 273)$ & $3.3 \%(\mathrm{n}=9 / 269)$ \\
\hline
\end{tabular}

hyperosmolality, hyperchloreamia, leukocytosis, thrombocytopenia and elevated serum urea levels.

The independent effects of factors that were significantly associated with hypernatreamia were investigated in multivariate analysis using stepwise forward Wald logistic regression. There was colinearity between elevated serum urea level and hyperchloreamia in the model and so hyperchloreamia was excluded from the logistic regression analysis. The multivariate OR of hypernatreamia was then calculated with its $95 \%$ CI. The multivariate analysis identified age $\geq 60$ years, altered level of consciousness and a new diagnosis of diabetes as significant and independent determinants of the presence of hypernatreamia at admission. Table 4 shows that the risk of hypernatreamia was increased 4 times respectively for admissions associated with age $\geq$ 60 years and a new diagnosis of diabetes. The risk for hypernatreamia was 10 fold higher with altered level of consciousness.

\section{Discussion}

The major findings of this study are a hypernatreamia prevalence rate of $11.7 \%$ based on uncorrected serum sodium $>145 \mathrm{mmol} / \mathrm{L}$ and $30.1 \%$ based on a serum sodium of $>145 \mathrm{mmol} / \mathrm{L}$ corrected for the ambient blood glucose concentration and the independent association of hypernatreamia with advanced age, altered level of consciousness and a new diagnosis of diabetes. The prevalence rate of $11.7 \%$ that we observed for uncorrected hypernatreamia is much higher than the $1.2 \%$ reported in another study [2] with similar definition of hypernatreamia (uncorrected serum sodium $>145 \mathrm{mmol} / \mathrm{L}$ ). Our admissions consisted of ketoacidosis, hyperosmolar nonketotic state and hyperglycaemia with hypernatreamia rates of $17.4 \%, 37.9 \%$ and $0 \%$ respectively. Further analysis of our ketoacidosis patients revealed a hypernatreamia rate of $83.3 \%$ for hyperosmolar ketoacidosis and $1.2 \%$ for non-hyperosmolar ketoacidosis. Perhaps, the study [2] with a hypernatreamia rate of $1.2 \%$ was predominantly patients with non-hyperosmolar ketoacidosis. Although hyperosmolar DKA is increasingly being reported in children [11,12] and adults [13,14], their hypernatreamia rates were not documented. The proportions of hyperglycaemic crisis admissions presenting with hyperosmolar DKA was $15.1 \%(\mathrm{n}=8 / 53)$ in one study [13], and $45 \%(\mathrm{n}=288 / 613)$ in another study [14].

As uncorrected serum sodium $>145 \mathrm{mmol} / \mathrm{L}$ was found in none of 119 hyperglycaemic and only 1 of 97 nonhyperosmolar ketoacidosis admissions, the specificity of uncorrected serum sodium $>145 \mathrm{mmol} / \mathrm{L}$ for the diagnosis of hyperosmolality was $99.5 \%$ based on calculated effective osmolality $>320$ mosmols $/ \mathrm{kg}$. The sensitivity of uncorrected serum sodium $>145 \mathrm{mmol} / \mathrm{L}$ for the diagnosis of hyperosmolality was $62.6 \%$ as 20 of 24 admissions for hyperosmolar ketoacidosis and 11 of 29 admissions for hyperosmolar non-ketotic state had uncorrected serum sodium $>145 \mathrm{mmol} / \mathrm{L}$. Thus while almost all admissions with presenting uncorrected serum sodium $>145 \mathrm{mmol} / \mathrm{L}$ were hyperosmolar, not all hyperosmolar admissions had initial uncorrected serum sodium level $>145 \mathrm{mmol} / \mathrm{L}$. This suggests that in our setting, hyperglycaemic patients with uncorrected serum sodium levels $>145 \mathrm{mmol} / \mathrm{L}$ should be managed as hyperosmolar states.

A study [15] that was conducted on patients admitted to an intensive care unit reported the mechanisms for hypernatreamia to include salt overload and fluid depletion with the use of sodium bicarbonate, mannitol, impaired urinary concentration and sepsis as the independent determinants of hypernatreamia. Unlike our patients who were already hypernatreamic at presentation, the patients in this study

Table 2 Comparison of demographic and clinical variables in hypernatreamic and non-hypernatreamic admissions based on uncorrected serum sodium $>145 \mathrm{mmol} / \mathrm{L}$

\begin{tabular}{|c|c|c|c|}
\hline & Hypernatreamia & Non-Hypernatreamia & $P$ value \\
\hline Age (years) & $51.7 \pm 21.4(n=32 / 32)$ & $50.2 \pm 19.6(n=241 / 241)$ & 0.7 \\
\hline Females (\%) & $68.8(n=22 / 32)$ & $61.8(n=149 / 241)$ & 0.4 \\
\hline Age $\geq 60$ years $(\%)$ & $53.1(n=17 / 32)$ & $34.4(n=83 / 241)$ & 0.04 \\
\hline Hypotension (\%) & $30.4(n=7 / 23)$ & $6.1(n=11 / 181)$ & $<0.00001$ \\
\hline Altered level of consciousness (\%) & $88.9(n=24 / 27)$ & $32.5(n=54 / 166)$ & $<0.00001$ \\
\hline New diagnosis of diabetes (\%) & $46.9(n=15 / 32)$ & $25.7(n=62 / 241)$ & 0.01 \\
\hline
\end{tabular}


Table 3 Comparison of biochemical variables in hypernatreamic and non-hypernatreamic admissions based on uncorrected serum sodium $>145 \mathrm{mmol} / \mathrm{L}$

\begin{tabular}{llll}
\hline & Hypernatreamia & Non-Hypernatreamia & P value \\
\hline Hyperosmolality (\%) & $96.9(n=31 / 32)$ & $9.3(n=22 / 237)$ & $<0.0001$ \\
Hyperchloreamia (\%) & $93.8(n=30 / 32)$ & $13(n=31 / 239)$ & $<0.0001$ \\
Leukocytosis (\%) & $83.9(n=26 / 31)$ & $60.7(n=142 / 234)$ & 0.01 \\
Thrombocytopenia (\%) & $32.3(n=10 / 31)$ & $9.4(n=22 / 234)$ & $<0.00001$ \\
Elevated Serum Urea (\%) & $27.6(n=8 / 29)$ & $54.9(n=130 / 237)$ & 0.006 \\
HbA1C > 7\% (\%) & $94.1(n=16 / 17)$ & $77.4(n=123 / 159)$ & 0.107 \\
Blood glucose (mmol/L) & $33.9 \pm 18.7(n=32)$ & $32.4 \pm 15.7(n=237)$ & 0.6 \\
\hline
\end{tabular}

[15] developed hypernatreamia in the course of hospitalization. Sodium bicarbonate, mannitol or hypertonic saline could not have been contributory to the hypernatreamia in our patients as there was no prior administration of these agents at their referring hospitals before presentation to us. In another study [16], 50\% of patients who developed hypernatreamia during hospitalization and $89 \%$ of patients presenting with hypernatreamia had urinary concentration defects primarily associated with diuretic therapy or solute diuresis. Although, our patients with hyperglycaemic crisis will expectedly have glycosuria induced diuresis, hypernatremia was mainly a problem in those who were elderly, had altered sensorium or were newly diagnosed with diabetes.

The independent association of age $\geq 60$ years with hypernatreamia may be partly explained by an increased threshold for thirst and vasopressin deficiency that is associated with ageing $[17,18]$. Therefore, patients with advanced age may become hypernatreamic due to inadequate compensatory increased oral fluid intake and renal fluid retention in the face of glycosuria induced osmotic diuresis. Altered level of consciousness, regardless of aetiology may result in hypernatreamic dehydration because the patient is unable to replenish renal fluids loss orally due to impairment of the mental state. As our study was not only retrospective but cross-sectional in design, we can only state that impaired mental state was associated with hypernatreamia. The study design does not permit for the exploration of a causal relationship between hypernatreamia and altered level of consciousness. A report [19] which found all patients with hyperosmolar non-ketoacidotic state to have altered level of consciousness did not indicate the serum sodium levels or any association of hypernatreamia to coma. It is interesting that a new diagnosis of diabetes was significantly independently associated with hypernatreamia. Although admission blood glucose levels was non-statistically higher in the newly diagnosed than known diabetic patients $(35.35 \pm 19.0 \mathrm{mmol} / \mathrm{L}$ versus $31.5 \pm 14.6 \mathrm{mmol} /$ $\mathrm{L}, \mathrm{P}=0.079$ ), the proportion of admissions with HbA1c level above $10 \%$ was more in the newly diagnosed than known diabetic patients $(87.7 \%$ versus $74.8 \%, \mathrm{P}=0.049)$. This suggests that the majority of patients with hyperglycaemic crisis as the first manifestation of diabetes had more severe chronic hyperglycaemia than previously diagnosed diabetic patients. Perhaps, these newly diagnosed diabetic patients consequently had more prolonged osmotic diuresis with hypernatreamic dehydration.

The findings from this study suggest that particular attention should be given to serum sodium levels in admissions for hyperglycaemic crisis associated with advanced age, unconsciousness at presentation and a new diagnosis of diabetes. These patients will require more attention to fluids therapy and may require prophylactic anticoagulation as all hypernatreamic admissions met the criteria for hyperosmolality.

Table 4 Independent and Significant determinants of Hypernatreamia [based on uncorrected serum sodium $>145$ $\mathrm{mmol} / \mathrm{L}]$ using logistic regression model

\begin{tabular}{|c|c|c|c|c|c|}
\hline Independent variables & $\begin{array}{l}\text { Beta } \\
\text { Coefficient }\end{array}$ & Standard Error & $\begin{array}{l}\text { Wald } \\
\text { Chi-square }\end{array}$ & $\begin{array}{l}\text { Odd Ratio } \\
\text { (95\% Confidence Interval) }\end{array}$ & $P$ value \\
\hline $\begin{array}{l}\text { Age groups: } \\
\geq 60 \text { years } \\
\text { versus } \\
<60 \text { years }\end{array}$ & 1.371 & 0.581 & 5.570 & $\begin{array}{l}3.9 \\
(1.3-12.3)\end{array}$ & 0.018 \\
\hline $\begin{array}{l}\text { Altered level of consciousness: } \\
\text { Yes versus No }\end{array}$ & 2.172 & 0.673 & 10.404 & $\begin{array}{l}8.8 \\
(2.3-32.8)\end{array}$ & $<0.001$ \\
\hline $\begin{array}{l}\text { New diagnosis of Diabetes: } \\
\text { Yes versus No }\end{array}$ & 1.301 & 0.581 & 5.015 & $\begin{array}{l}3.7 \\
(1.2-11.5)\end{array}$ & 0.025 \\
\hline Constant & -4.489 & 0.750 & 35.784 & & $<0.0001$ \\
\hline
\end{tabular}

Adjusted for systolic blood pressure, white cell count, platelet count and serum urea levels. 


\section{Limitations of study}

The limitations of this study include its retrospective design and determination of serum osmolality by calculation rather than laboratory measurement. We may have underestimated serum osmolality where osmotically active substances other than glucose and sodium are present in the serum as we calculated rather than measured the serum osmolality. Another limitation is that results of urine osmolality, urine specific gravity and urine electrolytes concentrations were not provided as these are not routinely done in our practice.

\section{Conclusions}

In this retrospective review of hospital records for hyperglycaemic crisis, we observed prevalence rate for hypernatreamia of $11.7 \%$ based on uncorrected serum sodium concentration. All hypernatreamic admissions met the criteria for hyperosmolality. Advanced age, altered conscious level and a new diagnosis of diabetes were independently associated with hypernatreamia.

\section{Acknowledgements}

Miss Q Duba is acknowledged for the invaluable efforts in making available the case notes that were reviewed.

\section{Author details}

'Department of Internal Medicine, Faculty of Health Sciences, Walter Sisulu University/Nelson Mandela Academic Hospital, Mthatha, Eastern Cape Province, South Africa. ${ }^{2}$ Biostatistics Unit, Lomo Medical Center and Heart of Africa Centre of Cardiology, Kinshasa, Democratic Republic of Congo. ${ }^{3}$ Department of Internal Medicine, Lagos State University Teaching Hospital, Ikeja, Lagos State, Nigeria.

\section{Authors' contributions}

COE conceived the study, participated in its design, collation of data and drafting of the manuscript. BLM participated in the study design, statistical analysis and interpretation of data and revising the manuscript for important intellectual content. AN participated in the study design, statistical analysis and interpretation of data. $\mathrm{AO}$ participated in the study design and drafting of the manuscript. NTT participated in the study design and revision of the manuscript critically for important intellectual content. All authors read and approved the manuscript.

\section{Competing interests}

The authors declare that they have no competing interests.

Received: 7 January 2011 Accepted: 18 April 2011

Published: 18 April 2011

\section{References}

1. Chiasson J, Aris-Jilwan N, Bélanger R, Bertrand S, Beuregard H, Ékoé J, Fournier H, Havrankova J: Diagnosis and treatment of diabetic ketoacidosis and the hyperglycaemic hyperosmolar state. CMAJ 2003, 168:859-66.

2. Newton CA, Raskin P: Diabetic ketoacidosis in Type 1 and Type 2 diabetes mellitus: clinical and biochemical differences. Arch Intern Med 2004, 164:1925-31

3. Ogbera AO, Awobusuyi J, Unachukwu C, Fasanmade O: Clinical features, predictive factors and outcome of hyperglycaemic emergencies in a developing country. BMC Endocrine Disorders 2009, 9:9.

4. Palmer BF: Approach to fluid and electrolyte disorders and acid-base problems. Prim Care Clin Office Pract 2008, 35:195-213.
5. Bagshaw SM, Townsend DR, McDermid RC: Disorders of sodium and water balance in hospitalized patients. Can J Anesth/J Can Anesth 2009, 56:151-67.

6. Barra SI, Beredo R, Kleinfeld M: Hypernatremia in the aging: causes, manifestations and outcomes. J of Natl Med Assoc 1995, 87:220-4.

7. Yee AH, Rabinstein AA: Neurologic presentations of acid-base imbalance, electrolyte abnormalities and endocrine emergencies. Neurol Clin 2010, 28:1-16.

8. Decaux G: Electrolyte and acid-base disturbances in diabetes mellitus. Acta Clinica Belgica 2004, 59:241-245.

9. American Diabetes Association: Hyperglycaemic crisis in diabetes. Diabetes Care 2004, 27(S1):S94-102.

10. Ekpebegh CO, Longo-Mbenza B, Akinrinmade A, Blanco-Blanco E, Badri MN, Levitt NS: Hyperglycaemic crisis in the Eastern Cape province of South Africa: High mortality and association of hyperosmolar ketoacidosis with a new diagnosis of diabetes. SAMJ 2010, 100:822-6.

11. Hudson O, Menon S, Kaufman S: Combined hyperglycaemic hyperosmolar syndrome with diabetic ketoacidosis as the presentation of Diabetes Type 2 in an Adolescent Female. Endotrends 2008, 15:1-5.

12. Dean $H$, Sellers $E$, Kesselman M: Acute hyperglycaemic emergencies in children with Type 2 diabetes. Paediatr Child Health 2007, 12:43-4.

13. Pepper DJ, Burch VC, Levitt NS: Hyperglycaemic emergency admissions to a secondary - level hospital - an unnecessary financial burden. SAMJ 2007, 97:963-7.

14. Wachtel TJ, Tetu-Mouradjian LM, Goldman DL, Ellis SE, O'Sullivan PS: Hyperosmolarity and acidosis in diabetes mellitus: a three - year experience in Rhode Island. J Gen Intern Med 1991, 6:495-502.

15. Hoorn EJ, Betjes MGH, Weigel J, Zietse R: Hypernatreamia in critically ill patients: too little water and too much salt. Nephrol Dial Transplant 2008, 23:1562-8.

16. Palevsky PM, Bhagrath $R$, Greenberg A: Hypernatreamia in hospitalized patients. Ann Intern Med 1996, 124:197-203.

17. Phillips PA, Rolls BJ, Ledingham JGG, Forsling ML, Morton JJ, Growe MJ: Reduced thirst after water deprivation in healthy elderly men. $N$ Engl J Med 1984, 311:753-9.

18. Faull CM, Holmes C, Baylis PH: Water balance in the elderly people: is there a deficiency of vasopressin? Age Ageing 1993, 22:114-120.

19. Faich GA, Fishbein HA, Ellis SE: The epidemiology of diabetic acidosis: a population based study. Am J Epidemiology 1983, 117:551-8.

\section{Pre-publication history}

The pre-publication history for this paper can be accessed here: http://www.biomedcentral.com/1472-6823/11/8/prepub

doi:10.1186/1472-6823-11-8

Cite this article as: Ekpebegh et al:: Advanced age, altered level of consciousness and a new diagnosis of diabetes are independently associated with hypernatreamia in hyperglycaemic crisis. BMC Endocrine Disorders 2011 11:8

\section{Submit your next manuscript to BioMed Central and take full advantage of:}

- Convenient online submission

- Thorough peer review

- No space constraints or color figure charges

- Immediate publication on acceptance

- Inclusion in PubMed, CAS, Scopus and Google Scholar

- Research which is freely available for redistribution

Submit your manuscript at www.biomedcentral.com/submit
C Biomed Central 